\title{
GMR
}

\section{Genetic variability of garlic accessions as revealed by agro-morphological traits evaluated under different environments}

\author{
E.S.S. Hoogerheide ${ }^{1,2}$, J.A. Azevedo Filho ${ }^{3}$, R. Vencovsky ${ }^{1 \dagger}$, M.I. Zucchi ${ }^{4}$, \\ B.W. Zago ${ }^{5}$ and J.B. Pinheiro ${ }^{1}$ \\ 'Departamento de Genética, Escola Superior de Agronomia “Luiz de Queiroz", \\ Universidade de São Paulo, Piracicaba, SP, Brasil \\ ${ }^{2}$ Embrapa Agrossilvipastoril, Sinop, MT, Brasil \\ ${ }^{3}$ Agência Paulista de Tecnologia dos Agronegócios, Monte Alegre do Sul, SP, \\ Brasil \\ ${ }^{4}$ Agência Paulista de Tecnologia dos Agronegócios, Piracicaba, SP, Brasil \\ ${ }^{5}$ Programa de Pós-Graduação em Biodiversidade e Biotecnologia - Rede \\ BIONORTE, Universidade do Estado de Mato Grosso, Cáceres, MT, Brasil \\ $\dagger$ In memoriam \\ Corresponding author: J.B. Pinheiro \\ E-mail: jbaldin@usp.br \\ Genet. Mol. Res. 16 (2): gmr16029612 \\ Received January 13, 2017 \\ Accepted January 23, 2017 \\ Published May 31, 2017 \\ DOI http://dx.doi.org/10.4238/gmr16029612
}

Copyright (C) 2017 The Authors. This is an open-access article distributed under the terms of the Creative Commons Attribution ShareAlike (CC BY-SA) 4.0 License.

ABSTRACT. The cultivated garlic (Allium sativum L.) displays a
wide phenotypic diversity, which is derived from natural mutations
and phenotypic plasticity, due to dependence on soil type, moisture,
latitude, altitude and cultural practices, leading to a large number
of cultivars. This study aimed to evaluate the genetic variability
shown by 63 garlic accessions belonging to Instituto Agronômico de
Campinas and the Escola Superior de Agricultura "Luiz de Queiroz"
germplasm collections. We evaluated ten quantitative characters in
experimental trials conducted under two localities of the State of São
Paulo: Monte Alegre do Sul and Piracicaba, during the agricultural

Genetics and Molecular Research 16 (2): gmr16029612 
year of 2007, in a randomized blocks design with five replications. The Mahalanobis distance was used to measure genetic dissimilarities. The UPGMA method and Tocher's method were used as clustering procedures. Results indicated significant variation among accessions $(\mathrm{P}<0.01)$ for all evaluated characters, except for the percentage of secondary bulb growth in MAS, indicating the existence of genetic variation for bulb production, and germplasm evaluation considering different environments is more reliable for the characterization of the genotypic variability among garlic accessions, since it diminishes the environmental effects in the clustering of genotypes.

Key words: Allium sativum L.; Clustering analysis; Multivariate analysis; Genetic variation

\section{INTRODUCTION}

Garlic (Allium sativum L.) is one of the oldest horticultural crops (García Lampasona et al., 2003) and is an important vegetable that has its origin in central Asia (Chen et al., 2013). The first record of growing garlic date 4000 years ago, since then has become one of the most popular crop worldwide, both as a medicine and a vegetable, being China the chief producer of garlic in the world and Brazil the largest importer (Chen et al., 2013; Lucena et al., 2016).

Although the obligatory apomixis is a limiting factor for the development of recombinant individuals of this species, cultivated garlic displays a wide phenotypic diversity, which is derived from natural mutations and phenotypic plasticity, due to dependence on soil type, moisture, latitude, altitude and cultural practices. Furthermore, natural and human selection for adaptation in growing regions led to a large number of cultivars (Volk et al., 2004; Viana et al., 2016).

The garlic cultivars grown in Brazil are commercially divided into two groups, the first group is known as noble garlic and the second group as common or semi-noble garlic. The common or semi-noble garlic varieties are adapted to the climatic conditions of southeastern Brazil and are recommended for cultivation in the State of São Paulo, due to its adaptation to the regional climatic conditions (Mota et al., 2005, 2006). Moreover, they do not require vernalization and are highly productive, presenting excellent commercial quality. Its bulbs and cloves are slightly purple, a desired characteristic for garlic (although noble cultivars display a more intense purple color). These cultivars produce on average 15 good-sized cloves per bulb. The undesirable, excessively thin cloves observed in some garlic bulbs are not produced by these semi-noble cultivars (Lisbão et al., 1993; Mota et al., 2006).

Due to its importance for genetic improvement, accessions of garlic are being conserved in germplasm banks in several countries, including Brazil (da Cunha et al., 2014; Silva et al., 2014), and the potential of this garlic diversity in germplasm banks can only be truly exploited when there is a proper characterization. Thus, it is possible to identify the most promising genotypes for genetic improvement and also benefit farmers, enabling the rational use of these genotypes in family farming (Coelho et al., 2010).

The characterization of a germplasm bank can be performed by using morphological, anatomical, isoenzymatic, and molecular traits of the accessions and the multivariate analysis can be used for the analysis of the information obtained in experiments, allowing the

Genetics and Molecular Research 16 (2): gmr16029612 
characterization of genotypes based on a combination of variables (Cruz and Regazzi, 2001). Clustering analysis has been used to facilitate the visual interpretation of genetic diversity in plants. The use of these techniques has been extensively reported in scientific studies on several crop species such as cassava (Nick et al., 2008; Campos et al., 2010), capsicum (Sudré et al., 2006; Bento et al., 2007; Aklilu et al., 2016), commom bean (Chiorato et al., 2005; Legesse et al., 2013), sugarcane (Sanghera et al., 2015), maize (Teodoro et al., 2015), onion (Buzar et al., 2007; Singh et al., 2013), açai palm (Oliveira et al., 2007), Brazilian turmeric (Sigrist et al., 2011), and garlic (Menezes Sobrinho et al., 1999; García Lampasona et al., 2003; Mota et al., 2006; Panthee et al., 2006; Zahedi et al., 2007; Viana et al., 2016), among others.

This study aimed to characterize the genetic variability in semi-noble garlic accessions from the germplasm banks of "Instituto Agronômico de Campinas" and the Genetics Department of the Escola Superior de Agricultura "Luiz de Queiroz", through multivariate analysis of quantitative traits in two different regions in the State of São Paulo.

\section{MATERIAL AND METHODS}

Sixty-three accessions of semi-noble garlic (Table 1) of the germplasm collections of Instituto Agronômico de Campinas (IAC) and of the Genetics Department of the Escola Superior de Agricultura "Luiz de Queiroz", University of São Paulo (ESALQ/USP), were evaluated.

The experimental trials were conducted in two different localities of the State of São Paulo: Monte Alegre do Sul (MAS) and Piracicaba (PCA). Experimental trials were installed between April 24 and 25, 2007, in MAS (Pólo APTA Regional Leste Paulista) and in May 7, 2007, in PCA (Genetics Department, ESALQ) in randomized blocks design with two to five replications (Table 1) according to the availability of accessions. Each plot consisted of four lines $1 \mathrm{~m}$ long, with plants $0.1 \mathrm{~m}$ spaced and lines $0.25 \mathrm{~m}$ spaced, being only the two central lines considered for the analyses. After harvesting, plants were submitted to sun exposure previously to storage in a ventilate shed. After 30 days of storage, the pseudostem was removed.

The agro-morphological evaluations were performed according to the recommendations of the Plant Genetic Resources Institute. Additionally, other relevant traits were evaluated. Ninety days after the emergence of the plants, the following traits were evaluated through the mean of six plants per plot: height of the plant from the soil to the superior leaf in $\mathrm{cm}$, width of the leaf, measured in the middle third part of the superior leaf, in $\mathrm{cm}$, length of the longest leaf, in $\mathrm{cm}$, number of leaves presenting photosynthetic activity and width of the base of the pseudostem in $\mathrm{cm}$.

At harvesting, we estimated the frequency of plants with secondary bulb growth dividing the number of plants showing this characteristic by the total number of plants. After 30 days of storage, we measured the total weight of bulbs, in kg per plot, the weight of commercial bulbs (i.e., those with diameter superior to $35 \mathrm{~mm}$ ), in $\mathrm{kg}$ per plot, and the number of cloves per bulb, obtained from a random sample of five bulbs.

With the aim of detecting the existence of variability among the accessions, the observed traits (considering the two localities separately) were submitted to univariate analyses of variance (ANOVA). Multivariate analyses were based on Mahalanobis distances, computed with standardized variables as provided by the GENES software (Cruz, 2006). The organization of the accession was investigated using UPGMA (unweighted pair group

Genetics and Molecular Research 16 (2): gmr16029612 
Table 1. Semi-noble garlic accessions evaluated, its institution and number of replications of trials conducted in Monte Alegre do Sul (MAS) and Piracicaba (PCA), 2007.

\begin{tabular}{|c|c|c|c|c|}
\hline Treatment & Accessions & Institution & MAS & PCA \\
\hline 1 & Canela de Ema & IAC & 5 & 5 \\
\hline 2 & Cara & IAC & 5 & 5 \\
\hline 3 & Mineiro & IAC & 5 & 5 \\
\hline 4 & Mossoró & IAC & 5 & 4 \\
\hline 5 & BGH-0525 & IAC & 5 & 5 \\
\hline 6 & BGH-4823 & IAC & 3 & 3 \\
\hline 7 & Andrada Manoel Lopez & IAC & 2 & 2 \\
\hline 8 & Assaí-3702 & IAC & 5 & 5 \\
\hline 9 & Piedade & IAC & 5 & 5 \\
\hline 10 & Santa Catarina Roxo & IAC & 5 & 5 \\
\hline 11 & Chinês-4653 & IAC & 5 & 5 \\
\hline 12 & Roxinho 5063 & IAC & 5 & 5 \\
\hline 13 & Peruano Bisão & IAC & 5 & 5 \\
\hline 14 & Mexicano Br & IAC & 3 & 3 \\
\hline 15 & Roxo Capim Branco & IAC & 5 & 5 \\
\hline 16 & Cateto Precoce I-99 & IAC & 5 & 5 \\
\hline 17 & Alho Bepe & IAC & 3 & 4 \\
\hline 18 & Formosa-4713 & IAC & 3 & 4 \\
\hline 19 & Lavínia-1632 & IAC & 5 & 5 \\
\hline 20 & BGH-5935 & IAC & 5 & 5 \\
\hline 21 & São José-4999 & IAC & 2 & 2 \\
\hline 22 & Catetinho do Paraná 1254 & IAC & 5 & 5 \\
\hline 23 & Mendonça-5062 & IAC & 5 & 5 \\
\hline 24 & Tatuí-3705 & IAC & 5 & 5 \\
\hline 25 & Gigante de Curitibanos & IAC & 5 & 5 \\
\hline 26 & Areal 23978 & IAC & 5 & 5 \\
\hline 27 & Vera Cruz-5004 & IAC & 5 & 5 \\
\hline 28 & BGH-4814 & IAC & 5 & 5 \\
\hline 29 & BGH-5947 & IAC & 5 & 5 \\
\hline 30 & Chinês ESALQ & IAC & 5 & 4 \\
\hline 31 & Cateto Roxo 99 & IAC & 5 & 5 \\
\hline 32 & BGH-5936 & IAC & 5 & 5 \\
\hline 33 & BGH-6394 & IAC & 4 & 5 \\
\hline 34 & BGH-5952 & IAC & 5 & 5 \\
\hline 35 & Chinês Esalq 2 & ESALQ & 5 & 5 \\
\hline 36 & Andradas M. Lopez 2 & ESALQ & 5 & 5 \\
\hline 37 & Roxo de Minas (Dr. Joaquim) & ESALQ & 5 & 5 \\
\hline 38 & Sr. Wilson (bairro Godoí) & ESALQ & 5 & 5 \\
\hline 39 & B. aéreo Gig. Curitibanos & ESALQ & 5 & 5 \\
\hline 40 & Chine Mogi & ESALQ & 5 & 5 \\
\hline 41 & Gigante & ESALQ & 5 & 5 \\
\hline 42 & Centenário & ESALQ & 5 & 5 \\
\hline 43 & Gigante Dez & ESALQ & 5 & 5 \\
\hline 44 & São José & ESALQ & 5 & 5 \\
\hline 45 & Lavínia & ESALQ & 5 & 5 \\
\hline 46 & Caiano Branco & ESALQ & 5 & 5 \\
\hline 47 & Cateto Branco & ESALQ & 5 & 5 \\
\hline 48 & Crespo & ESALQ & 5 & 5 \\
\hline 49 & Gigante Vinte & ESALQ & 5 & 5 \\
\hline 50 & Cajuru & ESALQ & 5 & 5 \\
\hline 51 & Peruano & ESALQ & 5 & 5 \\
\hline 52 & Ouro Fino & ESALQ & 5 & 5 \\
\hline 53 & Sergipe & ESALQ & 5 & 5 \\
\hline 54 & Mineiro Branco & ESALQ & 5 & 5 \\
\hline 55 & Babás & ESALQ & 5 & 5 \\
\hline 56 & Chinês Quatapara & ESALQ & 5 & 5 \\
\hline 57 & $\mathrm{~A}$ & IAC & 5 & 5 \\
\hline 58 & $\mathrm{~B}$ & IAC & 5 & 5 \\
\hline 59 & $\mathrm{C}$ & IAC & 5 & 5 \\
\hline 60 & $\mathrm{D}$ & IAC & 5 & 5 \\
\hline 61 & $\mathrm{E}$ & IAC & 5 & 5 \\
\hline 62 & $\mathrm{~F}$ & IAC & 5 & 5 \\
\hline 63 & Embrapa Cateto roxo livre de vírus & IAC & 5 & 5 \\
\hline
\end{tabular}

Genetics and Molecular Research 16 (2): gmr16029612 
method using arithmetic averages) and optimization Tocher's method. The matrix of distances was obtained first for each locality separately. Subsequently a matrix sum (Searle, 1966) was computed summing the corresponding elements of these two matrices. Congruence of distance measures of both locations was verified through a linear correlation coefficient, with significance obtained by the Mantel Z-test. Methodologies mentioned here are given by Cruz and Carneiro (2003).

\section{RESULTS AND DISCUSSION}

Results indicated significant variation among accessions $(\mathrm{P}<0.01)$ for all evaluated characters, except for the percentage of secondary bulb growth in MAS. These results are important because they indicate the existence of genetic variation for bulb production.

Genetic distances between pairwise accessions in MAS ranged from 0.2367 to 0.0068 (mean: 0.0620). The smaller distance was observed between accessions 61 (E) and 5 (BGH-0525), while accessions 62 (F) and 20 (BGH-5935) were the most divergent. In PCA, distances ranged from 0.5806 to 0.0010 (mean: 0.1397). Accessions 47 (Cateto Branco) and 48 (Crespo) displayed the smaller distance, while the largest one was observed between 54 (Mineiro Branco) and 27 (Vera Cruz-5004). It is worth noting that the pairs of accessions with maximum and minimum divergence are not the same in both localities. The first 20 pairs of accessions with higher and lower dissimilarities were compared between localities, and no correspondence was observed. This discrepancy is probably due to the influence of the environment. Draghi and Whitlock (2012) refers to the phenotypic plasticity to explain the magnitudes of variation observed in environmental-related traits, i.e., the same genotype or clone can show morphological variation according to environmental factors such as soil, climate, and humidity. This is probably because the garlic cultivars may show distinct characteristics in different environments, it may be noted significant differences in plant development, the length and width of the leaves in the crop cycle, the premature sprouting, conformation, size and bulb color and also in the number, size, shape, and coloring of bulbils (Vieira and Nodari, 2007).

This fact corroborates the results of Trani et al. (2005), who studied 50 garlic accessions of the IAC germplasm collection (many of those accessions are common to our study) and observed higher genetic variability for quantitative traits such as yield and bulb diameter in Jundiaí than in Tietê, both in the State of São Paulo. The authors stated that edaphoclimatic conditions and agronomic practices highly affect the yield of garlic culture.

Lucena et al. (2016) compared quality characteristics of semi-noble garlic cultivars subjected to different bulb-seed, pre-planting vernalization periods in two municipalities of the Western Mesoregion of Rio Grande do Norte State. The authors observed differences in the behavior of genotypes in relation to the bulb diameter in the two locations. When bulbseed vernalization was not performed, the cultivars showed larger bulb diameter in Barauna municipality, while in the municipality of Governador Dix-Sept Rosado, the diameter of the bulb was smaller for the genotypes. According to the authors, the difference in diameter of bulbs between planting locations can be related to the influence of climatic factors of each location.

Considering the matrix sum, it could be observed that the lowest genetic distance occurred between accessions 29 (BGH-5947) and 12 (Roxinho 5063), and the highest distance observed between accessions 54 (Cajuru) and 20 (BGH-5935). The mean of dissimilarities of this matrix considering all the accessions was 3.14. The distances varied from 2.03 to 5.21.

Genetics and Molecular Research 16 (2): gmr16029612 
Of the 63 accessions, 26 (42\%) displayed means equal or higher than the general mean (3.14). This suggests they encompass the highest genetic variability of the total sample. Accessions 54 (Cajuru) and 20 (BGH-5935) showed the highest means, and were the more frequent among the pairs of accessions with higher dissimilarities. Accession 20 was present in the pairs of accessions with higher dissimilarity in MAS and PCA; in the matrix sum, the more discrepant pair of accessions was formed by these accessions. Thus, they must be considered as indispensable for a germplasm collection.

The distribution of genetic distances, which is based on the 3969 pairs of accessions of the matrix sum, is shown in Figure 1. A strong asymmetry to the left side of the distances can be observed. The six first classes are formed by classes in which the distances varied from 0.47 to 5.18 , indicating that the accessions are genetically similar.

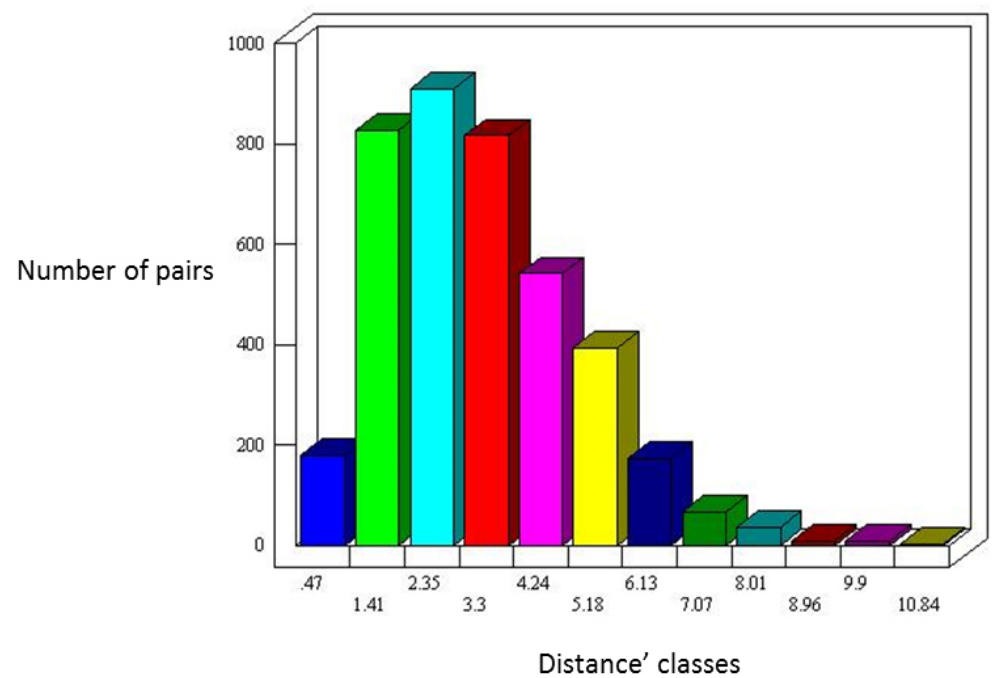

Figure 1. Frequency distribution of the Mahalanobis genetic distances among the 63 garlic accessions, considering both localities: Monte Alegre do Sul and Piracicaba.

When applying Tocher's method, considering the localities separately (Table 2), it is possible to note that there is no similarity in the distribution of the number of groups, once 18 groups were identified in MAS, being seven of them represented by a single accession; in PCA, nine groups were formed. The different measures for the same genotype in different localities indicate differential response to the environment. This may be attributable to the genotype $\mathrm{x}$ environment interaction.

Lisbão et al. (1993) evaluated the productivity of garlic accessions in three localities in São Paulo State: Monte Alegre do Sul (MAS), Pariquera-Açu and Guatapará, observing different yields among the localities. The authors observed that in MAS accessions IAC Lavínia 1632, Roxinho I-5063 and Peruano were superior, while in Pariquera-Açu, the superior accessions were Santa Catarina Roxo, Cajuru I-2315, São José 4999 and Areal no2I-3978; in Guatapará, the superior accessions were Peruano and Chinês. In our study, we also detected differential performance according to the environment. Accession Peruano (51) showed to be superior in both studies, being superior in MAS in the study of Lisbão et al. (1993), and superior in PCA in the present study.

Genetics and Molecular Research 16 (2): gmr16029612 
Table 2. Clustering of the 63 garlic accessions based on quantitative traits, using Tocher's method and Mahalanobis distances in Monte Alegre do Sul (MAS), Piracicaba (PCA), and the matrix sum.

\begin{tabular}{l|l|l|l}
\hline Groups & MAS & PCA & Matrix sum \\
\hline 1 & 56113834327626581859129 & 47485253504245514154 & 12293539254955598365643 \\
& 1210273135 & & 4661344023601610382613 \\
\hline 2 & 495552501642393656434846 & $\begin{array}{l}293625398512351034622860232455409 \\
163317305646266149194344385958614\end{array}$ & 474851504542535441 \\
\hline 3 & & 24175732 & 659758322811182127 \\
\hline 4 & 222462 & 1120211813 & 222462 \\
\hline 5 & 192925 & 1531 & 13 \\
\hline 6 & 414737543053 & 337 & 153133 \\
\hline 7 & 406038 & 22 & 1730 \\
\hline 8 & 112820 & 63 & 57 \\
\hline 9 & 1551 & 27 & 44 \\
\hline 10 & 4445 & & 19 \\
\hline 11 & 263 & & 52 \\
\hline 12 & 23 & & 14 \\
\hline 13 & 57 & & 37 \\
\hline 14 & 4 & & 63 \\
\hline 15 & 21 & & 20 \\
\hline 16 & 14 & & 4 \\
\hline 17 & 17 & & 2 \\
\hline 18 & 33 & & \\
\hline
\end{tabular}

Some similarities were observed in the clustering pattern of MAS and PCA (Table 2), where some accessions were clustered together in both localities, e.g., the groups formed by [8 (Assaí-3702), 5 (BGH-0525), 61 (E), 12 (Roxinho 5063), 35 (Chinês Esalq 2), 10 (Santa Catarina Roxo), 34 (BGH-5952), 9 (Piedade), 26 (Areal 23978), 59 (C), 58 (B), 6 (BGH-4823)]; [(48 (Crespo), 52 (Ouro Fino), 50 (Cajuru), 42 (Centenário)]; [32 (BGH5936), 7 (Andrada Manoel Lopez)], and [11 (Chinês-4657), 20 (BGH-5935)]. This shows that environmental interactions did not affect the similarity of these accessions for the quantitative traits evaluated.

When Tocher method was applied to the matrix sum, it discriminated 17 clusters (Table 2). Three main clusters encompassed $84.1 \%$ of the accessions, and 10 clusters were formed by a single accession. In the distances within clusters, the estimates for cluster 1 showed to be superior to the remaining clusters, indicating higher variability within this group. Considering the distances among clusters, clusters $1 \times 2$ were the more divergent, suggesting that they are formed by accessions with distinct characteristics.

The UPGMA hierarchic clustering method groups the individuals according to the arithmetic means of dissimilarity measures. The procedure is repeated in several levels until a tree or dendrogram is formed. In this situation, the optimal number of clusters does not matter, once we are interested in the topology of the dendrogram. The clusters can be identified by direct observation of the dendrogram, where different levels can be determined (Cruz and Regazzi, 2001). In the dendrogram generated by the UPGMA with the matrix sum (Figure 2), it is possible to observe that none of the accessions formed a divergent cluster, and several clusters with sub-clusters are observed. Considering as a cutting point the value of the general mean of distances ( $\mathrm{dgE}=3,1405)$, five clusters can be observed.

This can be compared to other studies on garlic, as the study of Panthee et al. (2006) which evaluated 179 garlic accessions from different regions of Nepal. The accessions were grown in two different localities and evaluated for quantitative and qualitative traits. Multivariate analysis revealed three main groups and the variability level observed showed great potential for the improvement of agronomic traits. Morales et al. (2013) studied the

Genetics and Molecular Research 16 (2): gmr16029612 
genetic similarity of 20 noble and semi-noble garlic cultivars, comparing 28 qualitative and quantitative morphological traits. The noble cultivars (Caçador, San Valetin, Bergamota, Ito, Quitéria, Jonas, Chonan, and Roxo Caxiense) were grouped in a single cluster, the same occurring to the semi-noble cultivars (Chines Real, Gigante Núcleo, Gigante Livinia, Hozan, Gravatá, and Gigante Roxo). The authors concluded that the morphological data from this study demonstrated that this technique is useful for distinguishing cultivars between groups.

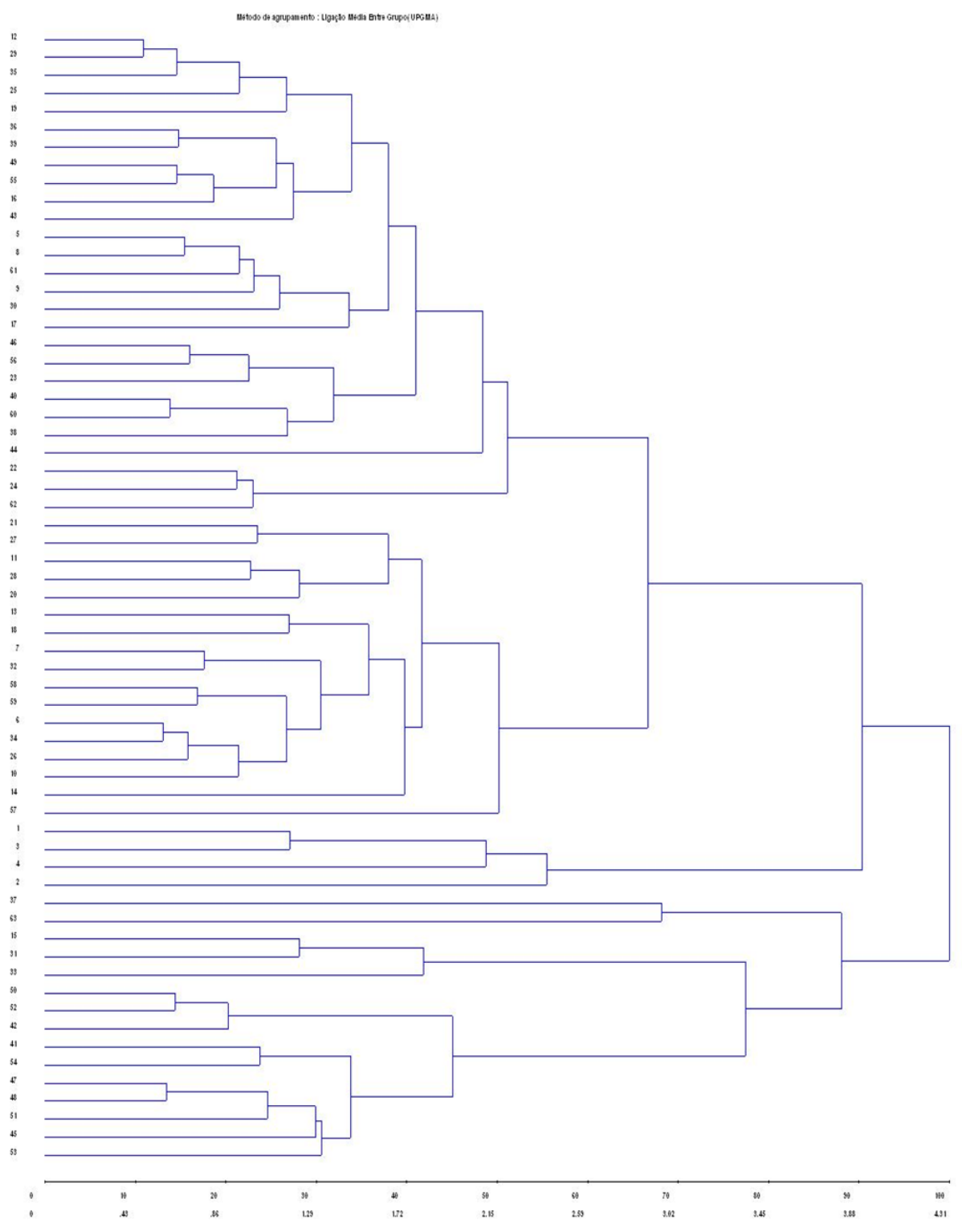

Figure 2. UPGMA dendrogram with 63 garlic accessions, considering both localities: Monte Alegre do Sul and Piracicaba.

Genetics and Molecular Research 16 (2): gmr16029612 
The correlation between the dissimilarity matrix between localities was low (0.3046), although significant. This indicates that the dissimilarity measure in each location did not represent the same distribution in the accessions, suggesting that clones varied according to the environment, probably due to an interaction between genotype and environment. Menezes Sobrinho et al. (1999) stated that climatic conditions play a major role in garlic yield, because the differential action of genes in different climatic conditions, for example, the photoperiod and temperature are the major influence on bulbification and hence the productivity and final economic result of the culture (Souza and Macêdo, 2009).

Thus, the results obtained here indicated that germplasm evaluation considering different environments is more reliable for the characterization of the genotypic variability among garlic accessions, since it diminishes the environmental effects in the clustering of genotypes. A critical choice of localities for accession evaluation is an important step when garlic germplasm is being studied.

\section{REFERENCES}

Aklilu S, Abebie B, Wogari D and Teklewold A (2016). Analysis of morphological diversity among hot pepper (Capsicum annuит L.) collections in the Rift Valley area of Ethiopia. Trop. Agric. (St Augustine) 41: 152-164.

Bento CS, Sudré CP, Rodrigues R, Riva EM, et al. (2007). Descritores qualitativos e multicategóricos na estimativa da variabilidade fenotípica entre acessos de pimentas. Sci. Agric. 8: 149-156.

Buzar AGR, Oliveira VR and Boieux LS (2007). Estimativa da diversidade genética de germoplasma de cebola via descritores morfológicos, agronômicos e bioquímicos. Hortic. Bras. 25: 527-532. http://dx.doi.org/10.1590/S0102$\underline{05362007000400007}$

Campos AL, Zacarias AJ, Costa DL, Neves LG, et al. (2010). Avaliação de acessos de mandioca do banco de germoplasma da UNEMAT Cáceres - Mato Grosso. Rev. Trop. Ci. Agr. Biol. 4: 44-54.

Chen S, Zhou J, Chen Q, Chang Y, et al. (2013). Analysis of the genetic diversity of garlic (Allium sativum L.) germplasm by SRAP. Biochem. Syst. Ecol. 50: 139-146. http://dx.doi.org/10.1016/j.bse.2013.03.004

Chiorato AF, Carbonell SAM, Colombo CA, Dias LAS, et al. (2005). Genetic diversity of common bean accessions in the germplasm bank of the Instituto Agronômico - IAC. Crop Breed. Appl. Biotechnol. 5: 1-9. http://dx.doi. org/10.12702/1984-7033.v05n01a01

Coelho CMM, Zilio M, Souza CA, Guidolin AF, et al. (2010). Características morfo-agronômicas de cultivares crioulas de feijão comum em dois anos de cultivo. Semin. Cienc. Agrar. 31: 1177-1186. http://dx.doi.org/10.5433/16790359.2010v31n4Sup1p1177

Cruz CD (2006). Programa Genes: Análise multivariada e simulação. 1st edn. UFV Press, Viçosa.

Cruz CD and Regazzi AJ (2001). Modelos biométricos aplicados ao melhoramento genético. 2nd edn. UFV Press, Viçosa.

Cruz CD and Carneiro PCS (2003). Modelos biométricos aplicados ao melhoramento genético. 3rd edn. UFV Press, Viçosa.

da Cunha CP, Resende FV, Zucchi MI and Pinheiro JB (2014). SSR-based genetic diversity and structure of garlic accessions from Brazil. Genetica 142: 419-431. PubMed http://dx.doi.org/10.1007/s10709-014-9786-1

Draghi JA and Whitlock MC (2012). Phenotypic plasticity facilitates mutational variance, genetic variance, and evolvability along the major axis of environmental variation. Evolution 66: 2891-2902. PubMed http://dx.doi.org/10.1111/j.15585646.2012.01649.x

García Lampasona SG, Martínez L and Burba JL (2003). Genetic diversity among selected Argentinean garlic clones (Allium sativum L.) using AFLP (Amplified Fragment Length Polymorphism). Euphytica 132: 115-119. http:// dx.doi.org/10.1023/A:1024606004596

Legesse H, Dechassa N, Gebeyehu S, Bultosa G, et al. (2013). Multivariate Analysis as a Tool for Indirect Selection of Common Bean Genotypes (Phaseolus vulgaris L.) for Soil Acidity Tolerance under Field Conditions. Sci. Technol. Arts. Res. 2: 7-15.

Lisbão RS, Siqueira WJ, Fornasier JB and Trani PE (1993). Avaliação de cultivares de alho. In: O Melhoramento de Plantas no Instituto Agronômico (Cangiari AM, Furlani AMC and Viégas GP, eds.). Instituto Agronômico Press, Campinas.

Lucena RRM, Negreiros MZD, Morais PLDD, Lopes WDAR, et al. (2016). Qualitative analysis of vernalizated semi-

Genetics and Molecular Research 16 (2): gmr16029612 
noble garlic cultivars in western Rio Grande do Norte State, Brazil. Rev. Caatinga 29: 764-773. http://dx.doi. org/10.1590/1983-21252016v29n329rc

Menezes Sobrinho JA, Charchar JM and Aragão FAZ (1999). Caracterização morfológica de germoplasma de alho por análises multivariadas, componentes principais e variáveis canônicas. Hortic. Bras. 17: 96-111. http://dx.doi. org/10.1590/S0102-05361999000200004

Morales RGF, Resende JTV, Resende FV, Delatorre CA, et al. (2013). Genetic divergence among Brazilian garlic cultivars based on morphological characters and AFLP markers. Genet. Mol. Res. 12: 270-281. PubMed http:// dx.doi.org/10.4238/2013.February.4.1

Mota JH, Noce R, Yuri JE, Resende GM, et al. (2005). Análise da evolução da produção risco-retorno para a cultura do alho, no Brasil e regiões (1991 a 2000). Hortic. Bras. 23: 238-241. http://dx.doi.org/10.1590/S0102-05362005000200015

Mota JH, Yuri JE, Resende GM and Souza RJ (2006). Similaridade genética de cultivares de alho pela comparação de caracteres morfológicos, físico-químicos, produtivos e moleculares. Hortic. Bras. 24: 156-160. http://dx.doi. org $/ 10.1590 / \mathrm{S} 0102-05362006000200006$

Nick C, Carvalho M, Assis LHB and Carvalho SP (2008). Genetic dissimilarity in cassava clones determined by multivariate techniques. Crop Breed. Appl. Biotechnol. 8: 104-110. http://dx.doi.org/10.12702/1984-7033.v08n02a02

Oliveira MSP, Ferreira DF and Santos JB (2007). Divergência genética entre acessos de açaizeiro fundamentado em descritores morfoagronômicos. Pesqui. Agropecu. Bras. 42: 501-506. http://dx.doi.org/10.1590/S0100204X2007000400007

Panthee DR, Kc RB, Regmi HN, Subedi PP, et al. (2006). Diversity analysis of garlic (Allium sativum L.) germplasms available in Nepal based on morphological characters. Genet. Resour. Crop Evol. 53: 205-212. http://dx.doi. org/10.1007/s10722-004-6690-Z

Sanghera GS, Kumar R, Tyagi V, Thind KS, et al. (2015). Genetic divergence among elite sugarcane clones (Saccharum officinarum L.) based on cane yield and quality traits from northern India. J. Exp. Biol. 3: 184-190.

Searle SR (1966). Matrix algebra for the biological sciences. John Willey and Sons Press, New York.

Sigrist MS, Pinheiro JB, Azevedo Filho JÁ and Zucchi MI (2011). Genetic divergence among Brazilian turmeric germplasm using morpho-agronomical descriptors. Crop Breed. Appl. Biotechnol. 11: 70-76. http://dx.doi.org/10.1590/S1984$\underline{70332011000100010}$

Silva AR, Cecon PR, Dias CTS and Puiatti M (2014). Morphological phenotypic dispersion of garlic cultivars by cluster analysis and multidimensional scaling. Sci. Agric. 71: 38-43. http://dx.doi.org/10.1590/S0103-90162014000100005

Singh SR, Ahmed N, Lal S and Ganie SA (2013). Determination of genetic diversity in onion (Allium cepa L.) by multivariate analysis under long day conditions. Afr. J. Agric. Res. 8: 5599-5606.

Souza RJ and Macêdo FS (2009). Cultura do alho: tecnologias modernas de produção. 1st edn. UFLA Press, Lavras.

Sudré CP, Cruz CD, Rodrigues R, Riva EM, et al. (2006). Variáveis multicategóricas na determinação da divergência genética entre acessos de pimenta e pimentão. Hortic. Bras. 24: 88-93. http://dx.doi.org/10.1590/S0102$\underline{05362006000100018}$

Teodoro PE, Ribeiro LP, Correa CCG, Silva FA, et al. (2015). Genetic divergence among maize hybrids in cerradopantanal ecotone. Biosci. J. 31: 1319-1324. http://dx.doi.org/10.14393/BJ-v31n5a2015-26236

Trani PE, Passos FA, Foltran DE, Tivelli SWL, et al. (2005). Avaliação dos acessos de alho pertencentes à coleção do Instituto Agronômico de Campinas. Hortic. Bras. 23: 935-939. http://dx.doi.org/10.1590/S0102-05362005000400015

Viana JPG, Pires CJ, Pinheiro JB, Valente SES, et al. (2016). Genetic diversity in garlic germplasm. Cienc. Rural 46: 203209. http://dx.doi.org/10.1590/0103-8478cr20130988

Vieira RL and Nodari RO (2007). Diversidade genética de cultivares de alho avaliado por marcadores RAPD. Cienc. Rural 37: 51-57. http://dx.doi.org/10.1590/S0103-84782007000100009

Volk GM, Henk AD and Richards CM (2004). Genetic diversity U.S. garlic clones as detected using AFLP methods. $J$. Am. Soc. Hortic. Sci. 129: 559-569.

Zahedi B, Kashi AK, Zamani Z, Mosahebi GH, et al. (2007). Evaluation of Iranian Garlic (Allium sativum L.) genotypes using multivariate analysis method based on morphological characteristics. Biotechnology 6: 353-356. http://dx.doi. org/10.3923/biotech.2007.353.356

Genetics and Molecular Research 16 (2): gmr16029612 